\title{
Structure Changing in Maize-Based Agriculture Production in Vietnam: Case Study in Son La Province
}

\author{
Dang Thi Thanh Thuy ${ }^{1 *}$, Nguyen Van Hieu ${ }^{2}$ \\ ${ }^{1,2}$ Capacity Development Center for Environment and Natural Resources (CEN), Hanoi, Vietnam \\ *E-mail: thuydang.cen@gmail.com
}

\begin{abstract}
Maize is the primary food resource for livestock, mainly cultivated in the northern mountains, the central provinces, and the central highlands in Vietnam. By studying reliable reports and policies related to maizebased agricultural production in combination with interviews and focus group discussion methods conducted in Son La province, this study specifically analyzes the situation of maize production in Vietnam and impacts of policies for the specific case in Son La province. The research results show that, though the sharp decrease, maize has still been the main crop with an annual cultivation area of over $30 \%$ of the country's agricultural land recently. However, maize is only modestly mentioned in some central policies, and no policy at the local level is reserved for maize production. In addition, maize is no longer a crop to attract local farmers' and authority' interest, especially since 2015, the transition in maize cultivation area on sloping land to arable land of fruit trees and many other crops has been carried out on a large scale due to some policies by the province, resulting in a sharp decrease in maize cultivated area and production. This might lead to limited results of substantial government policies on maize acreage expansion, maize cultivated area planning, or maize development strategy. Accordingly, some recommendations to improve the situation are provided.
\end{abstract}

Keywords: maize-based agriculture production, maize production, maize cultivation on sloping land, sustainable production.

\section{Introduction}

Since the last three decades, Vietnam's agricultural growth both meets the demand for food supply and raw materials for the domestic industry, service development, and also contributes to the export market [1]. In order to achieve food security and reducing poverty rates while keeping agricultural production sustainable remains a priority agenda [2].

In Vietnam, maize is known as the primary material resource for $90 \%$ demands of livestock and poultry feed. The demand for maize has been increased due to the strong development of animal husbandry [3]. To support maize production, a series of development-oriented and supportive policies have been issued, typically the Decision No. 5448/QD-BNN-TT dated December 28, 2016, by the Ministry of Agriculture and Rural Development (MARD) which refers to the national plan of maize production to 2025 and orientation to 2030. Accordingly, by 2020, maize is one of the crops to be encouraged to produce in large scale areas for animal feed.

Son La is a mountainous province in the northwest of Vietnam, where about $80 \%$ of arable land is sloping and reserved for industrial plantation crops, fruit trees production, and annual cultivation crops (among those, maize cultivated land occupies the most area). For many years, maize has become the second most important crop after rice in the locality [4]. Maize is cultivated in most localities, including steep areas of over 25 degrees and the areas of difficult infrastructure for maize production. Over a long time, the traditional maize cultivation by the "Fire cultivation method" has severely caused soil erosion, reduction of crop yields, and soil degradation [4]. However, for the past five years, maize is no longer a crop to attract local farmers' and authorities' interest due to the 
unstable market and the changes in agricultural development policies by Son La authority, resulting in a strong impact on maize production in the province.

At present, no research on the policies of maize or maize-based agricultural production has been conducted. Therefore, this study, through the case study in Son La province, will provide the audience with practical analysis on maize production and update policies related to maize-based agriculture in Vietnam as well as the implementation status of these policies at the locality. At the same time, relevant recommendations will be provided with the aim to limit the gaps or shortcomings of the policies and partly contribute to improving the management quality.

\section{Methods}

The main methods were combined including desk study, observation; semi-structured interview; expert interview and focus group discussion. These methods employed utilized its interinfluence and complementariness.

The target audience for interviews and discussion were some leaders, managers, researchers within MARD and Son La province, and also farmers and traders to understand how the policies have come into effect in practice.

At first, the review was based on a desk study of relevant policies relating to the agriculture which directly or indirectly impact to maize production, including those are i) issued by the Government and ii) issued by MARD, related ministries and agencies, and iii) and issued by Son La provincial and local authorities/agencies, etc. Specifically, these policies were divided into different groups with a focus on policies of sustainable production and support measures (credit and finance scheme, agricultural extension service, etc.). Additionally, the review was also based on all relevant documents relating to maize such as annual reports, statistics from governmental agencies/authorities, and Son La province; policy research reports and articles published in books, newspapers, magazines, websites; and other reliable sources. After that, the review was followed by expert interviews and focus group discussions in Hanoi and Son La (including districts of Yen Chau and Moc Chau).

\section{Results and Discussion}

\subsection{Maize production in Vietnam}

In Vietnam, maize is known as the primary material resource for livestock and poultry feed. It is also the raw material source for ethanol production-E5 gasoline. Therefore, maize has been grown in almost 8 agro-ecological regions of Vietnam including the North West, the North East, the Red River Delta, the North Central Coast, the South Central Coast, the Central Highlands, and the South East and the Mekong River Delta [5]. The figures for maize plantation area and production in Vietnam achieved at a very high growth rate from 1995 to 2015 . According to statistics revealed by MARD in 2015, the total area of maize plantation in the whole country was exactly $1,179.3$ thousand ha; the average productivity was about 4.48 tons/ha, and crop yield stood at 7.6 million tons.). The increase in area was only 1.04 times, but the increase in production was about 1.48 times compared to the figure in 2010. The rapid increase in maize productivity was recorded due to the application of technical advances, using hybrid maize varieties into mass production (over $90 \%$ of the total maize cultivated area in the whole country). But since 2015, the maize planted area and crop yield began a downward trend (Figure 1). By 2019, the maize cultivated area reached only 998.5 thousand hectares (down $15.3 \%$ compared to 2015), maize production reached 4.76 million tons (down 9.8\% compared to 2015). At present, the maize cultivated area has been just about $69 \%$ as the plan and the crop reached only about $55 \%$. 
As revealed at the National Agricultural Extension Forum in July /2019 in Son La that despite the dramatic decrease in maize cultivation, maize has been still a major crop with a large annual cultivated area of over $30 \%$ of agricultural land in the agricultural production structure of the northern provinces in 2019 [6]. However, Vietnam's corn productivity is below the genetic potential of modern varieties and the world average. In 2019, Vietnam's maize yield achieved 4.77 tons/ha which was lower than the world average yield (5.76 tons/ha), Asia (5.37 tons/ ha) and far lower than corn productivity in developed countries like the US (11.08 t/ha), France (8.75 t/ha) and China (6.11 t/ha) [7].

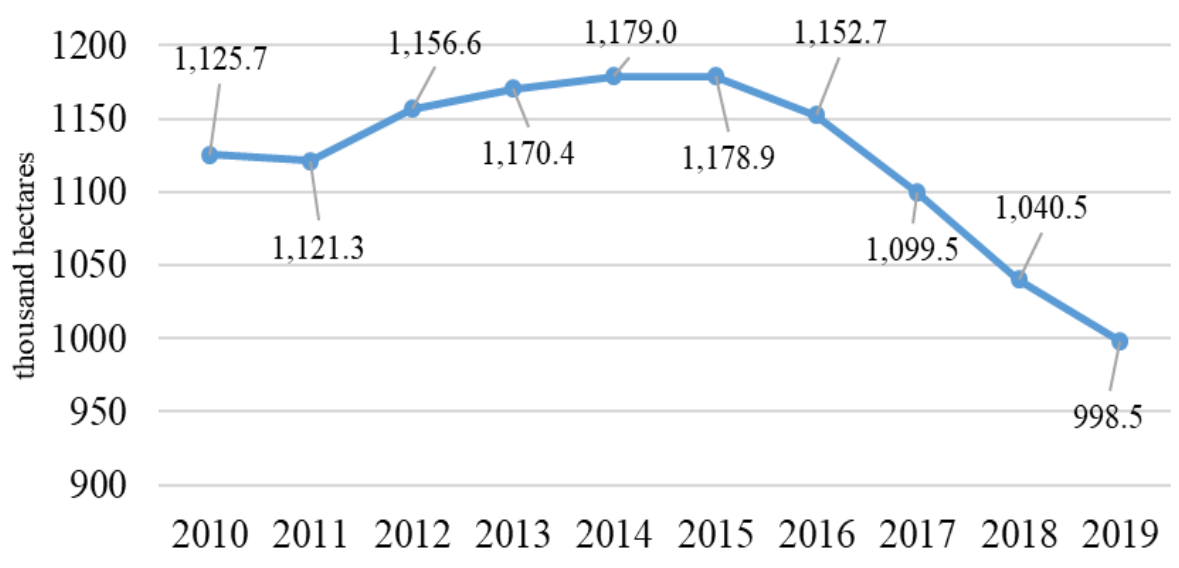

Figure 1

Maize cultivation area in Vietnam from 2010 to 2019

Source: MARD (2010-2019)[8]

Some objective and subjective reasons for low productivities could be as follows: Firstly, maize production in Vietnam has faced many challenges of climate change (such as unusual drought, floods, and storms), the scarcity of freshwater resources, and soil degradation in the sloping land. Secondly, the lack of varieties that could adapt well to unfavorable weather conditions has resulted in the underachievement of the full potential of those new varieties. Another reason that the application of farming techniques has not met the requirements of the new varieties despite certain improvements over the years.

Currently, Vietnam's maize production has provided only $40-50 \%$ of maize for domestic demand [9]. The domestic maize production could not meet the domestic demand resulting in the request to import maize from other countries (India, Brazil, Thailand, and Argentina were the four largest exporters to the Vietnam market). In 2010, the volume of imported corn was 1.77 million tons (equally to $38.49 \%$ of domestic maize production. By 2019, the volume of imported corn reached 11.57 million tons which were 6.5 times compared to the volume in 2010 and 2.43 times higher than the domestic production of maize (Figure 2). Among those, Vietnam imported maize much more from Argentina and Brazil. These were the two main markets, accounting for $63 \%$ and $36 \%$ market share respectively [10], [11]. 


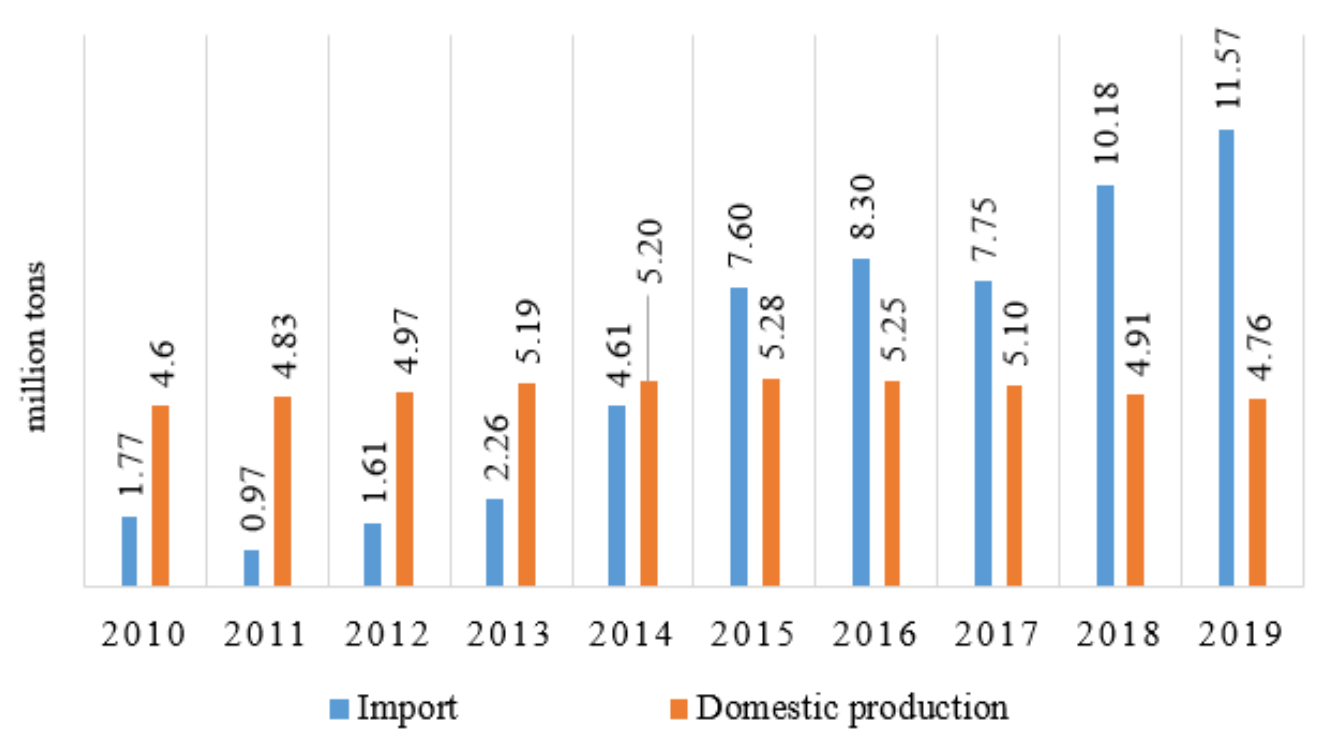

Figure 2

Domestic maize production and importation in Vietnam from 2010 to 2019

Source: MARD (2010-201)[8]

The area for maize cultivation decreased in most localities throughout the country due to some main reasons, among those, unstable selling prices of maize were the core factor encouraged farmers to reduced production. In addition, many midlands and mountainous provinces in the north are changing the structure of plantation on sloping land from maize or low-value crops to fruit trees or other crops which could bring higher economic value. Furthermore, unusual weather conditions with heavy rains and droughts in some areas caused by damages on cultivation and production. As a result, some cultivation transformation trends have occurred among farmers' groups in provinces: farmers in Thanh Hoa, Dak Lak, Dong Nai, Son La shifted to grow other crops which may bring higher economic value, while those in Ha Tinh, Nghe An, Son La switched to grow corn for biomass to serve dairy farming, deer farming. Additionally, the farmers in Daklak and Son La reduced their intercrop area of corn for long term trees.

\subsection{Maize production in Son La province}

Son La is located in the northwest of Vietnam, where about $80 \%$ of sloping cultivated land is reserved for maize, industrial plants, fruit trees, and other annual crops, among those, maize cultivation occupied the most sloping area. There are 12 districts in Son La, including Bac Yen, Mai Son, Moc Chau, Muong La, Phu Yen, Quynh Nhai, Song Ma, Sop Cop, Thuan Chau, Van Ho, Yen Chau.

The province is divided into different climatic sub-regions and diverse lands with a natural area of over $14,000 \mathrm{~km}^{2}$, ranking the third largest province of the country, with 365,213 hectares of agricultural production land. For a long time, maize production used to be considered as the province's strong growing crop. 


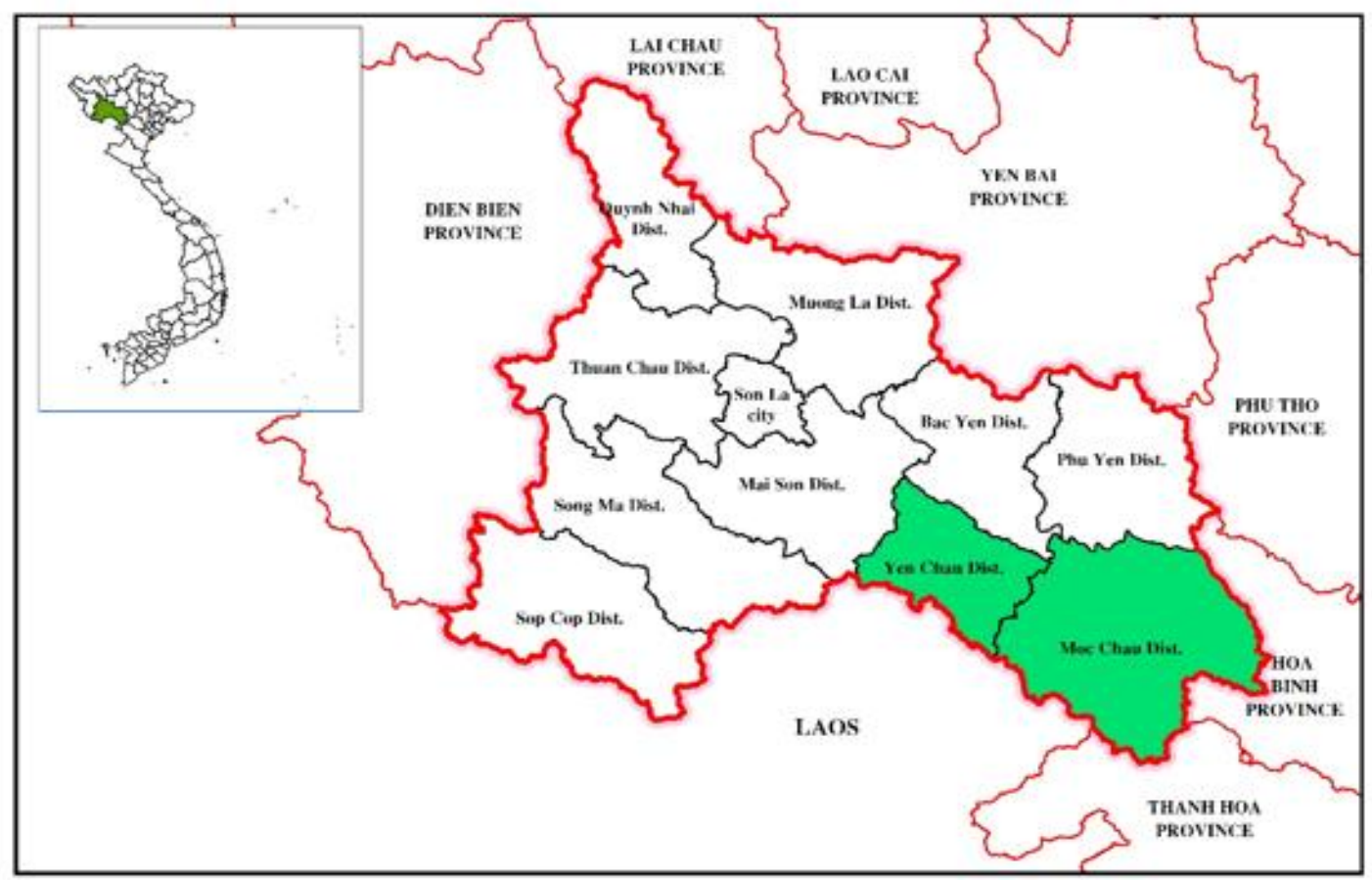

Figure 3

Map of Son La province, Vietnam

From 1995 to 2012, the maize cultivation area in Son La increased sharply. In 2012, the cultivated area reached 168.7 thousand hectares, accounting for $14.6 \%$ of the national cultivated corn area. Over $80 \%$ of annual maize production was purchased, preserved by local farmers and enterprises then sold to the animal feed processing enterprises outside the province; the rest served local needs. As reported by the Department of Agriculture and Rural Development of Son La province (Son La DARD), in 2007, the province's maize production was 444 thousand tons, peaked to 667.3 thousand tons in 2012 (this year, the area of maize cultivation reached the biggest figure so far). From 2015, the area for maize farming was significantly decreased and the maize productivity was thoroughly declined. Up to December 2019, maize crop yield in Son La was only 510.4 thousand tons (Figure 4).

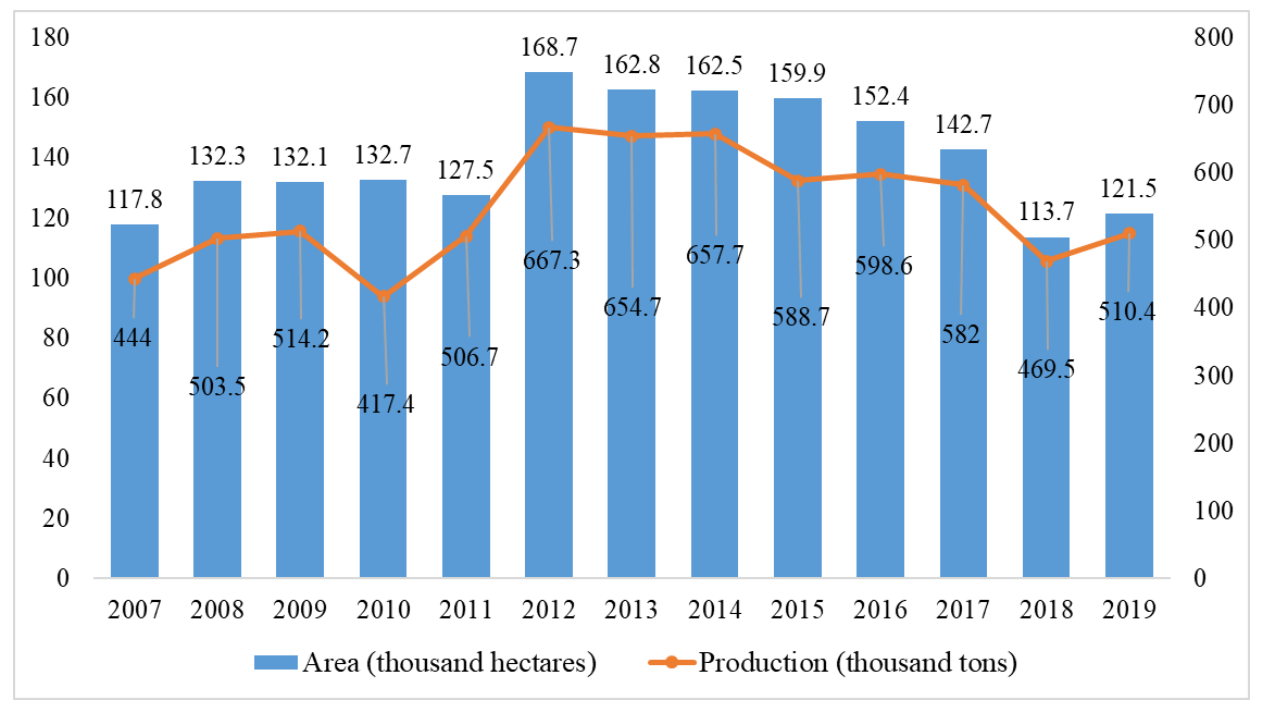

Figure 4

Maize cultivated area and crop yield in Son La between 2007 and 2019

Source: Son La DARD (2007-2019)[12] 
As revealed by a study in 2015, the erosion rate at sloping land of above 20 degrees can be up to 400 tons /ha/year [13]. In Son La, maize has been cultivated in many steep areas of over 25 degrees, even "climbed to the top of the hill".

Not only cultivating on steeply sloping land, leading to increased erosion, the abuse of chemical fertilizers in large quantities and inappropriately also "contributes" to damage to the soil and the surrounding environment. The interviews with farmers revealed that the average amount of fertilizers applied for maize per hectare per crop was $750 \mathrm{~kg}$ of NPK, $300 \mathrm{~kg}$ of urea, and $150 \mathrm{~kg}$ of potassium. These fertilizers were applied twice (basal application before plantation and additional fertilization when the corn has 5-6 leaves). The amount of fertilizer application is about 1.5 times higher than the recommended figure [14].

In terms of crop yields, the average maize yield in Son La achieved only 4.20 tons/ha, much lower than the national average figure (4.77 tons/ha). However, maize productivity has improved significantly, partly due to the adoption of new varieties. If in 2015 , the yield was only 3.71 tons/ha, this number in 2019 increased by $11.7 \%$ compared to the previous four years (Figure 5). Over the past 10 years, more than 50 varieties of hybrid maize have been grown in Son La province which has brought high yield and quality such as LVN10, LVN17, LVN4, and LVN25. In addition, there were some sticky maize varieties such as MX2, MX4, WAX22, S2, VN2, and VN6.

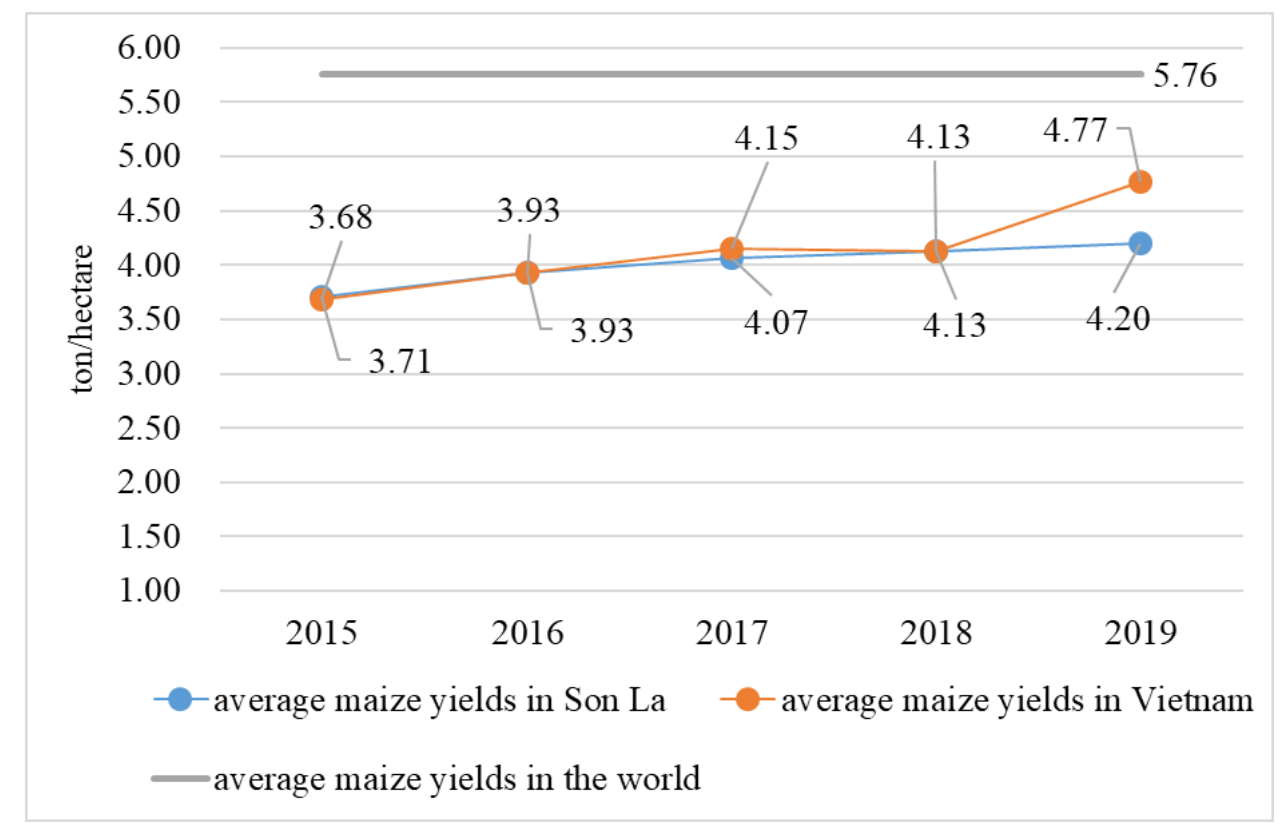

Figure 5

Maize productivity in Son La from 2015 to 2019

Source: Son La DARD (2007-2019)[12], MARD (2010-2019)[8], FAO (2017 [7]

However, after the period of increasing in maize productivity and cultivated areas, the farmers have faced many difficulties and unsustainable production problems such as soil erosion, landslides, environmental pollution, and degradation of arable land. In addition, many localities were strongly affected by the hot weather, drought and stem/corn borers resulted in crop losses (especially in 2010 and 2015). Maize productivity decreased by 20-70\% compared to other years. In 2019, large cultivated areas were destroyed due to the prolonged hot weather and harmful pests. In many maize-growing areas, the armyworms appeared and damaged hundreds of hectares of maize. As complained by the local maize farming households that nearly $80 \%$ of their maize cultivated land were seriously affected [15]. 
To deal with the unsustainable maize farming in the locality, some technical solutions for maize sustainable cultivation on sloping land have been studied and experimentally applied in Son La such as non-burning techniques or perennial plantation to cover mulch on the arable land. The mulching techniques not only help to prevent soil erosion but also contribute to reduce weeds, to keep moist and increase soil organic matters. In combination with mulching covering, the intercropping techniques have experimented with which use indigenous legumes such as soybeans, local red peanuts, rice beans, and H'mong peas to intercrop with maize in a row-by-planting manner to increase ground cover and land rehabilitation. At the same time, the technique of preparing small terraces combined with land mulching covering has been also tested. Moreover, the application of the agroforestry model has been also a pilot technical solution for maize cultivated sloping areas in Son La. Recently, producing biomass maize for livestock has been a new direction to improve local farmers' income.

Regarding the economic efficiency of maize cultivation land utilization in Son La, the efficiency of capital use ranged from 1.54 to 1.7 , was much lower than other crops such as plum (3.98), peach (4.28), longan (5.66), upland rice (4.33) (Figure 6).

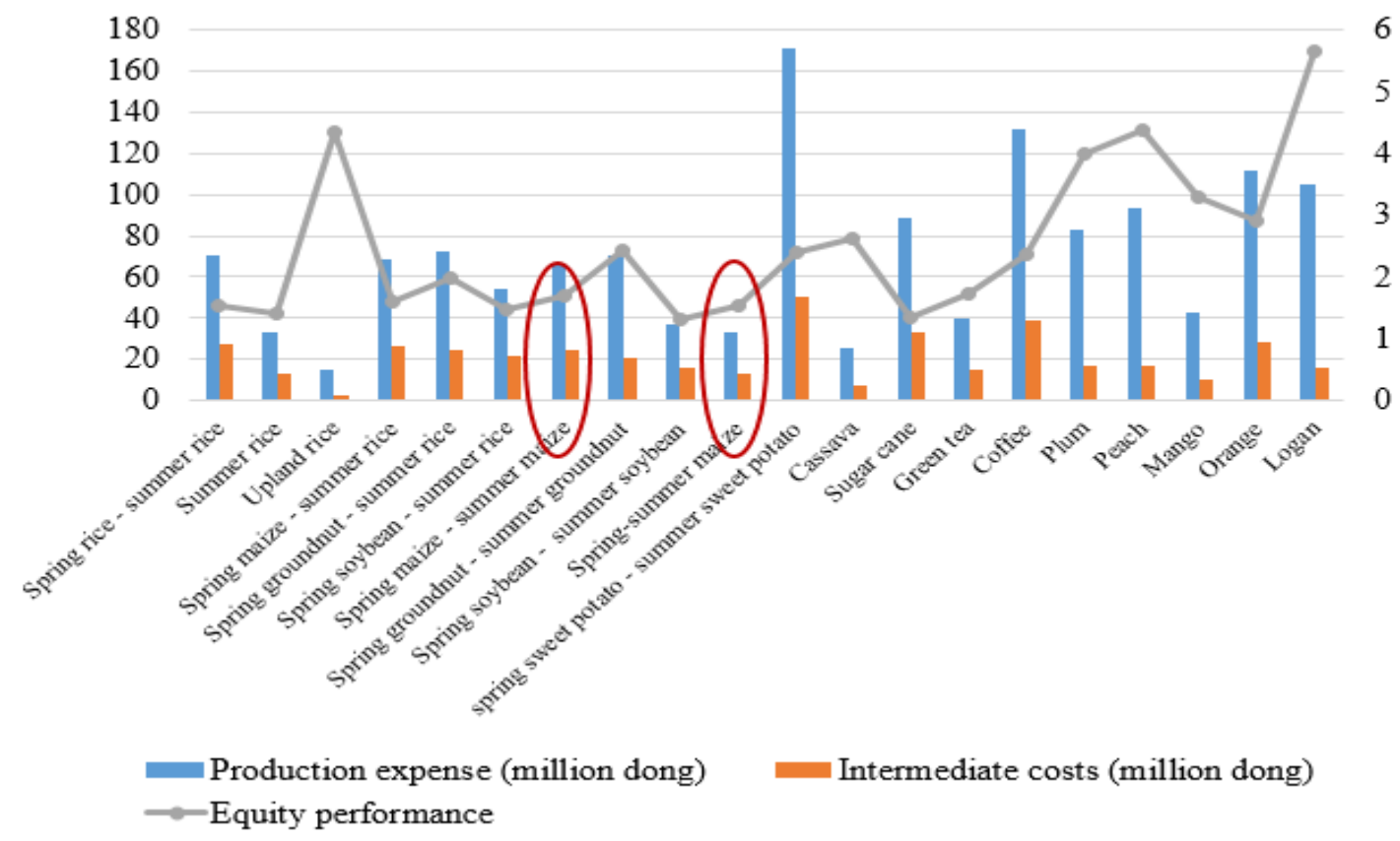

Figure 6

The efficiency of agricultural land use in Son La province Source: Toan, LD (2016)[16]

\subsection{The cultivation transition on maize production land in Son La}

Starting in 2015, the maize cultivated area and production were recorded in a sharp decrease. In the period 2015-2019, the maize acreage in Son La dropped by $24.05 \%$, from 159.9 thousand ha (2015) to 121.5 thousand ha (2019). Remarkably, Song Ma district was the locality with the largest decline in the area (down 7,339 ha, equivalent to nearly $50 \%$ of the maize cultivated area), Phu Yen district (down 6,990 thousand ha, equivalent to nearly $50 \%$ of the area), followed by Moc Chau and Mai Son districts (Figure 7). 


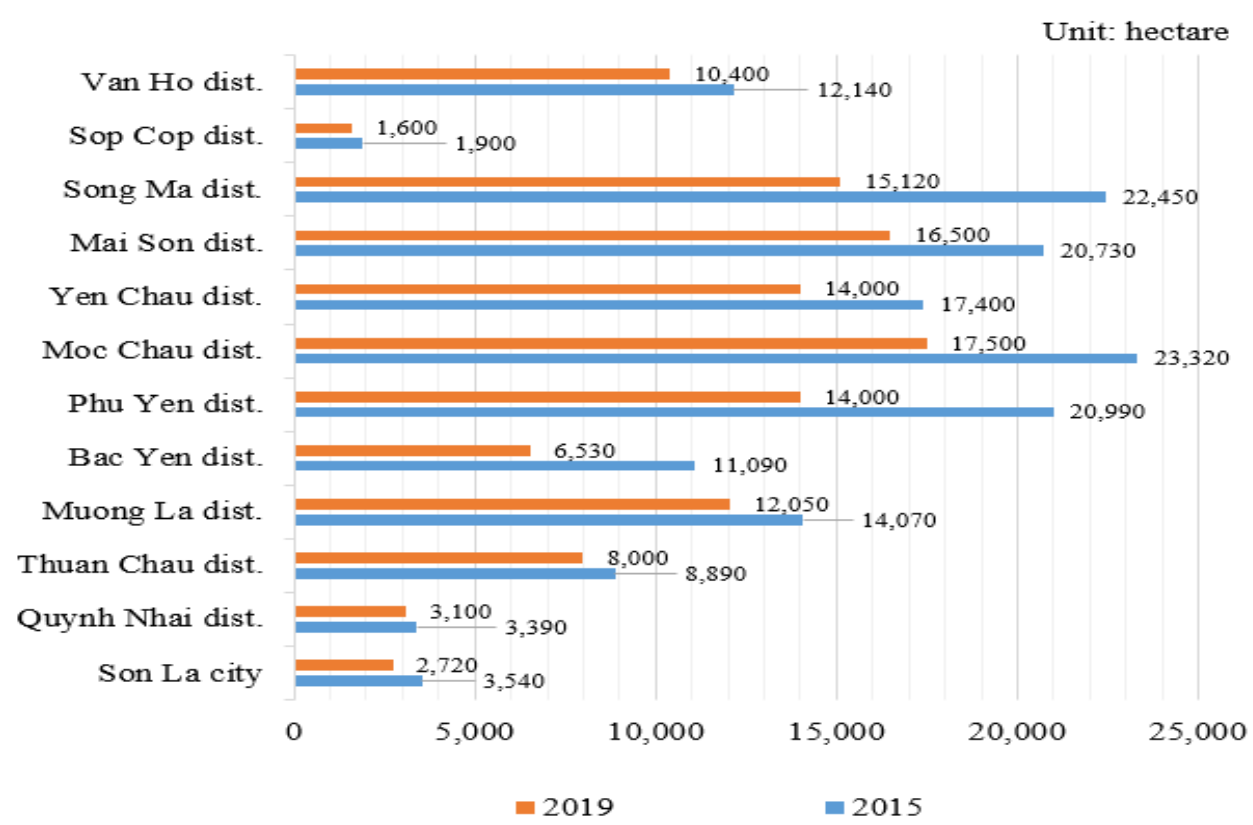

Figure 7

The change in maize cultivated area in Son La from 2015 to 2019

Source: Son La DARD (2007-2019)[12]

To develop sustainable production, Son La province's authority promulgated some policies which directed the transition of crops on "inefficient sloping land" (mainly from maize cultivation land) to plantation of highly qualified fruit trees. Since then, areas of maize cultivation fell down sharply. Especially, Resolution No.28/2017/NQ-HDND in 2017 stipulated the support for renovating mixed gardens and planting fruit trees which encouraged many farming households to change their cultivation methods by conducting the hybrid trials and grafting Taiwanese mangoes; planting Dien pomelos, oranges and bananas alternately on the cultivated area (Figure 8).

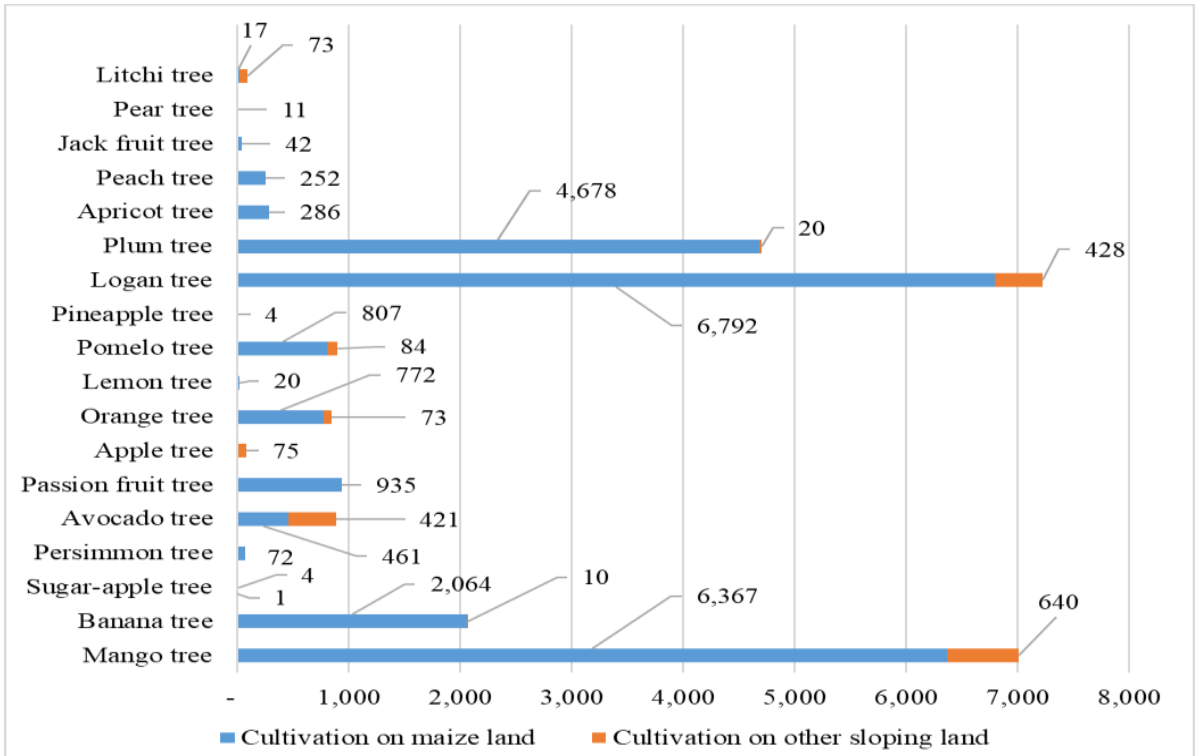

Note: Cultivation on other land includes: (i) Cultivation on upland rice fields; (ii) Cultivation on cassava fields; (iii) Cultivation on coffee fields.

\section{Figure 8}

The transition of cultivated areas on sloping land in Son La Source: Son La Statistics Department (2019) [17] 
Among cultivated crops on sloping land, the transition area of maize cultivation took the largest proportion. Accordingly, by the end of 2018, the total area of maize cultivation changed to fruit tree plantation accounted for 23,578 ha (recorded as $92.8 \%$ of the transition area). The area and structure of changed crops on upland maize are shown in Figure 9.

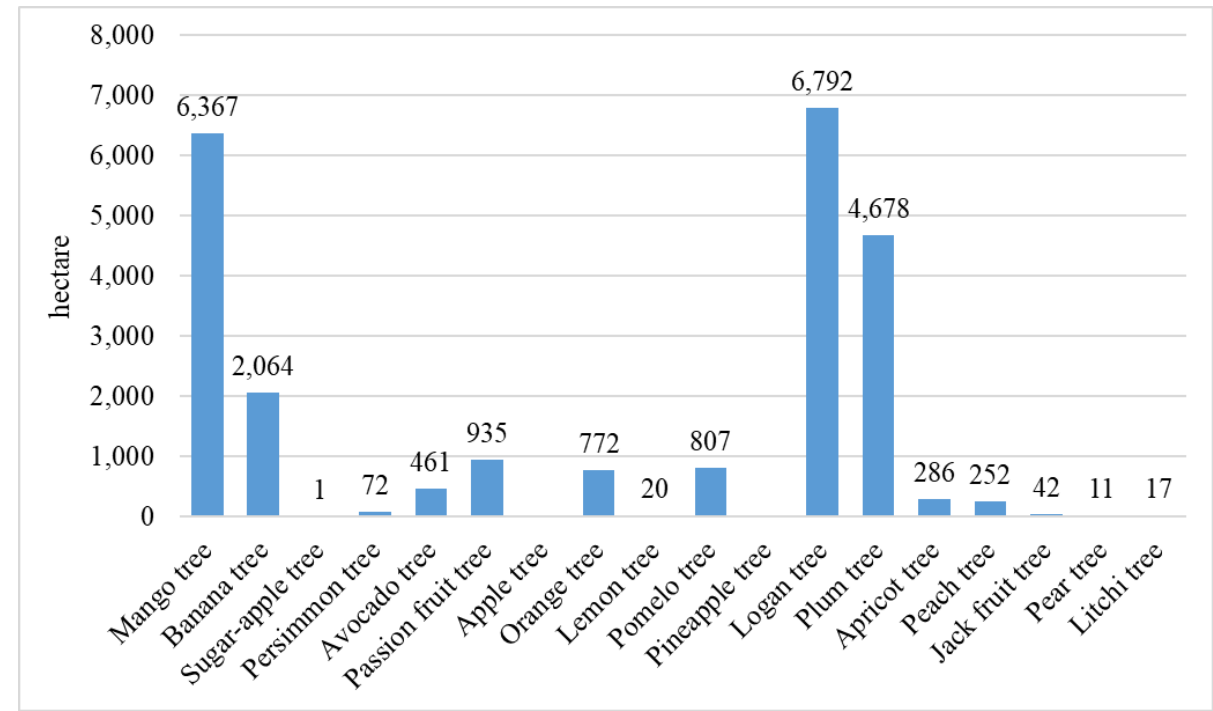

Figure 9

Transition crop area on the maize cultivation land in Son La Source: Son La Statistics Department (2019)[17]

Like many other districts in Son La province, maize in Yen Chau and Moc Chau districts have been cultivated in a large area and used to be a major crop to help reduce poverty. These are also the type localities for their production transition from maize into fruit trees or other crops and sustainable agricultural farming models that bring about high economic values.

In the Yen Chau district, once known as "the capital of maize" in Son La, maize is no longer the main crop although the largest area of maize cultivation accounts for $50.4 \%$ of agricultural cultivated area (2019). Maize production area in the district declined sharply in the period of 20152019 , from the figure of 17,400 ha in 2015 to 14,000 ha in 2019, down $19.54 \%$ [18]. Starting in 2016, some maize varieties with high and stable productivity have been applied in Yen Chau. In particular, the GM varieties supplied by Syngenta Company have been widely selected by local farmers in the district, especially the varieties NK66Bt/GT, NK7328Bt/GT, NK67Bt /GT, NK4300Bt/GT. These varieties are resistant to pests and diseases. They also bring much higher profits than those of normal maize varieties. However, these GM varieties have not assessed their impacts on the environment, ecosystems, and human health before developing on a large scale. In 2019, the maize cultivated area in Yen Chau accounted for 11,698 hectares, achieved 83.6\% of the district plan's objective. This decrease came from the local farmers' active activity to change their production from low-yield maize cultivation to biomass maize for animal feed. This conversion has contributed to increase the economic value for maize and to ensure food reservation for livestock, bringing stable income to farmers. Moreover, local farmers also transited some areas to cultivate fruit trees and other crops such as mango, longan, bananas, plum ... as suggested by the province and district directions on the development of fruit trees on sloping land.

In Moc Chau district, maize cultivated area dropped significantly in the period of 2015-2019, at $32.8 \%$, from 23,320 ha to 15,672 ha [19]. In 2019 , the maize production area increased by 1,828 hectares compared to the figure in 2018 because local farmers changed some of their cultivated areas to biomass maize production for dairy food composting. One of the important reasons for this 
change is the effect of the Decision No.2070/QD-UBND dated August 25, 2018, by Son La Provincial People's Committee (the policy focused on the plan to implement the livestock restructuring in the area in the period of 2018-2020, with an orientation to 2030), resulting in the increasing demand for biomass maize. In order to provide food resources for the dairy cows, the enterprises have cooperated with local farmers to produce biomass maize. Among those, Moc Chau dairy cows joint-stock company consumes a big amount of biomass and grain corn with a total area of about 7,000-8,000 ha (about $42 \%$ of the maize production area).

\subsection{Policy recommendations}

The analysis above shows that maize acreage and production has been declining sharply due to the shifting crop structure on sloping land as directed by the local policies. Furthermore, the province's authority does not pay attention to maize production development, therefore, no policy on maize development or maize production support has been recorded. Although the increasing demand for biomass maize, the low price, and economic efficiency compared to other crops caused the decrease in maize cultivation area in the locality. This may lead to the risk that some substantial government policies could not be implemented in practices such as the Decision No.124/QD-TTg dated February 2, 2012, on expanding maize acreage after 2020 or MARD's strategy on maize production development in accordance with the Decision No.824/QD-BNN-TT on April 16, 2012, or the Decision No.1384/QD-BNN-KH on June 18, 2013.

In order to implement the strategies and plans in practice effectively, there is a need to conduct researches to have the local feedbacks and situation update for policy adjustment to fit with the local status. This activity will support the localities effectively to implement the crop restructuring plan under Decision No.1006/QD-BNN-TT on May 13, 2014, and the national plan on maize production till 2025, with orientations towards 2030, in accordance with the Decision No.5448/QD-BNN-TT. When the policies are implemented well which will contribute to maintain a stable area of maize cultivation nationwide and to achieve high yields according to the targets. At the same time, there should be specific guidelines in implementation for the localities to ensure the achievement of the policies' goals.

Policymakers should pay their attention to the policies that emphasize development trends and models of suitable agriculture production to adapt to the local climate conditions, soils, and soil erosion protection in sloping areas as Son La case. In addition, the policymakers should also focus on the policies in stabilizing the output markets for local products (including maize products). In particular, the local stakeholders should be participated and consulted in the process of policymaking and implementation monitoring.

Local authorities and management agencies in Son La province should review and classify the current status of crops; analyze soil physical and chemical compositions, classification of cultivated land in localities; assess climatic conditions, natural water sources, irrigation systems for agricultural production, transportation systems for harvested products in sloping areas. Based on the results of the analysis, evaluation, and classification of production land, the professional management agencies should propose to the authorities to state in the local plans of arable land with the relevant land where meet the natural and social conditions. The local agencies should closely cooperate with national and international research organizations and scientists to evaluate and identify relevant crops and classify cultivated land for each region. Additionally, the agencies should also provide recommendations to local farmers in the selection of suitable crops for each soil type and climate of each region in the province.

Furthermore, there should be priority policies on production techniques, varieties, facilities and markets to support farmers, producers, and traders. In addition, there should be policies to encourage the localities and pioneer farmers to apply sustainable farming techniques on sloping 
land, including maize cultivation area. At the same time, local farmers should be provided essential supports to overcome difficulties in applying cultivation techniques on sloping land such as minimal land preparation, intercropping of legumes, planting of grass benches, sub-ladders. More researches should be conducted to assess the impacts of these technical measures when widely applied by farmers which will provide a scientific basis for building appropriate mechanisms and policies to promote the application of these practices in the whole region.

\section{Conclusion}

Maize is the main source for animal and poultry feed, being the second most important crop after rice in Vietnam as well as in Son La. For the past few years, maize has remained on the list of leading crops in the context of the strong development of crop production and livestock sector in the region. Maize production has been still maintained in the upland areas. However, in the last 5 years, the area of maize cultivation has decreased sharply. This leads to the risk that big policies of the Government and MARD cannot be implemented.

In Son La, maize is no longer the main crop in the province although the area is still very large. Over the last 5 years, maize acreage and maize production have decreased significantly due to the increasing transition from maize production to fruit trees and other crops on sloping land. From 2015 to 2019, the maize acreage in Son La decreased by 24.05\%. In particular, a sharp decrease in maize cultivation areas was recorded in many districts such as Song Ma and Phu Yen (down nearly $50 \%$ of the area, the majority area for maize farming was converted to fruit trees production).

In order to implement the strategies and plans in practice effectively, the policymakers and local governments should conduct studies and/or get the feedbacks from the localities to amend, supplement or issue relevant mechanisms, policies that should be applied in the local practice. These tasks aim to make the agriculture restructure successfully and to ensure the sustainable and effective production of crops on sloping land such as fruit trees or maize.

\section{Acknowledgments}

The authors would like to thank Vietnam National Department of Crop Production (under MARD), Department of Agriculture and Rural Development of Son La province, Division of Crop Production and Plant Protection of Son La province; the leading board of Yen Chau and Moc Chau People's Committees; Division of Agriculture of Yen Chau and Moc Chau districts; People's Committee and social unions of Yen Son and Chieng Hac communes; local farmers and the director of 19/5 cooperative for sharing and providing related documents or information.

In addition, we would like to thank the managers and staff of project SMCN-2014-049 for their supports and advice during the study. We also thank Ms. Tran Thi Anh Thu (MARD) for her useful supports to connect resource persons. Finally, we give our sincere thanks to the Capacity Development Center for Environment and Natural Resources (CEN) for the special supports to the team's activities.

\section{References}

[1] Mai N N, Anh D T. (2018). A Review of Vietnam's Recent Agricultural Policies. Available from: htpp://ap.fftc.agnet.org.index.php (access date: 02/2/2020).

[2] Karimov A, Thinh N T, Cadilhon J J, Tung H T, Hai D T, Van Doan V, Duan B Q. (2016) Value chain assessment report for maize, pig, plum, and tea in Son La province of Northwest Vietnam. ILRI Project Report. Nairobi, Kenya: ILRI. 
[3] Kha L Q \& Tuong L Q (2019). Biomass maize - Farming, harvesting, and processing techniques for animal husbandry. Agricultural Publishing House. Hanoi, Vietnam.

[4] Keil A, Saint-Macary C \& Zeller M. (2008). Maize boom in the uplands of Northern Vietnam: economic importance and environmental implications. Available from: https://ageconsearch.umn.edu/ record/92829 (access date: 11/1/2020).

[5] MARD. (2011). Report on the orientation and solutions to develop maize cultivation in winter and spring-winter crops in the northern provinces. Hanoi, Vietnam.

[6] Chien M. (2019). Solutions to prevent maize from armyworm in maize, National Agricultural Extension Forum on 24/7/2019 in Son La. Available from https://nongnghiep.vn/giai-phap-phongchong-sau-keo-mua-thu-d246105.html (access date: 05/3/2020).

[7] FAO. (2017). Crop statistics. Available from: http://www.fao.org/faostat/en/?\#data/QC (access date: $15 / 10 / 2020)$.

[8] MARD. Annual agriculture reports from 2010 to 2019. Hanoi, Vietnam. 2010-2019.

[9] Hong N T. (2017) An overview of agricultural pollution in Vietnam: Crop production. A report prepared for the World Bank, World Bank, Washington, D.C.

[10] Vietnam Customs (2020). Commodity import statistics in December 2019. Hanoi, Vietnam.

[11] Vietnam Customs (2020). Statistics of imported commodities from some countries/territories divided by main goods in December 2019. Hanoi, Vietnam.

[12] Son La DARD. Annual reports on the situation of agriculture from 2007 to 2019. Son La, Vietnam. 2007-2019.

[13] Pimentel D \& Burgess M. (2013). Soil erosion threatens food production. Agriculture, 3(3):443-463.

[14] MARD. (2012). Research report on application of technical and market solutions to improve the efficiency of corn and soybean production in some northern mountainous provinces of Vietnam. Hanoi, Vietnam.

[15] Cuong D \& Cuong N. (2019). The new pest infects hundreds of hectares of maize in Moc Chau. Available from: https://dantocmiennui.vn/xa-hoi/sau-la-gay-hai-hang-tram-ha-ngo-tai-moc-chau/ 230972.html (access date: 25/2/2020).

[16] Toan L D. (2016). Studying limitation factors in Son La's agricultural land and proposing solutions. Hanoi, Vietnam: Hanoi National University.

[17] Son La Statistics Department (2019). Statistical report on fruit tree production on sloping land. Son La, Vietnam.

[18] People's Committee of Yen Chau district. Annual report on the agriculture from 2016 to 2019. Yen Chau, Son La, Vietnam. 2015-2019.

[19] People's Committee of Moc Chau district. Annual report on the agriculture from 2015 to 2019. Moc Chau, Son La, Vietnam. 2015-2019. 